\title{
ESR SPECTROSCOPY OF ALANINE IMPACTED BY HIGH ENERGY IRRADIATIONS FOR WIDE RANGE DOSIMETRY
}

\author{
T. Čeponis ${ }^{\text {a }}$,E. Gaubas ${ }^{\text {a }}$, J. Venius ${ }^{\text {b }}$, A. Cicinas ${ }^{\text {b }}$, F. Callens ${ }^{\text {c }}$, J. Kusakovskij ${ }^{c}$, \\ H. Vrielinck ${ }^{c}$, K. Mizohata ${ }^{d}, J$. Raisanen ${ }^{d}$, and P. Tikkanen ${ }^{d}$ \\ ${ }^{a}$ Vilnius University Institute of Applied Research, Sauletekio 9, LT-10222 Vilnius, Lithuania \\ ${ }^{\mathrm{b}}$ National Cancer Institute, Santariškiu 1, LT-08660 Vilnius \\ 'Department of Solid State Sciences, Ghent University, Krijgslaan 281 - S1, B-9000 Ghent, Belgium \\ ${ }^{\mathrm{d}}$ Department of Physics, Helsinki University, Pietari Kalmin katu 2, FI-00014 Helsinki, Finland \\ E-mail: tomas.ceponis@ff.vu.lt
}

Received 26 June 2015; revised 20 July 2015; accepted 29 September 2015

\begin{abstract}
The ESR spectrometry, based on alanine dosimeters, is a standard tool for dosimetry of different type ionizing radiations. The calibrated dosimeters and ESR readers operate rather reliably in the dose range up to $200 \mathrm{kGy}$. In this study, the ESR spectrometry of stable free radicals in alanine, induced by penetrative $\mathrm{X}$ - and $\gamma$-rays as well as neutron and stopped proton irradiations covering the dose range from a few Gy to a few MGy, has been performed in order to create the generalized calibration function for the wide range dosimetry. The simulations based on the cumulative generation of ESR active stable radicals R1, R2 and R3 enabled us to derive the generalized calibration model ascribed to the irradiation fluence from $10^{10}$ to $2 \times 10^{16}$ particle $/ \mathrm{cm}^{2}$ normalized using $1 \mathrm{MeV}$ neutron equivalent.
\end{abstract}

Keywords: ESR spectroscopy, dosimetry, alanine

PACS: $76.30 .-v, 87.53 . \mathrm{Bn}, 87.55 . \mathrm{N}-$

\section{Introduction}

Alanine $\left(\mathrm{CH}_{3} \mathrm{CH}\left(\mathrm{NH}_{2}\right) \mathrm{COOH}\right)$, an amino acid, is one of the most standardized organic materials for fabrication of the irradiation dose sensors [1], as it enables to cover a rather wide range of measured doses with high accuracy using commercial dose readers [2] that operate as calibrated and specialized ESR spectrometers. The alanine dosimeters are very attractive in biomedical applications due to similarity of alanine features to human body tissues. Alanine sensors operate reliably when an electron spin resonance (ESR) signal is proportional to an irradiation dose. By applying the microwave (MW) radiation and varying the magnetic field the unpaired electron transitions occur when the energy difference between spin states equals the microwave quantum energy. Measurements of the absorbed MW energy yield the ESR spectrum. The peak-to-peak amplitudes of the most intensive peaks determine the amount of radicals formed by irradiation. Then the radiation dose is evaluated by using the reference dosim- eters calibrated for the specified irradiations and involving alternative techniques. The characteristic ESR spectrum of irradiated alanine has a rather invariable structure [3-7] caused by the existence of a set of radiation formed free radicals R1-R3 that show a long time stability after irradiation. The combined examination of the electron nuclear double resonance (ENDOR) and ESR spectra [8-10] elucidated the structure of free R1$\mathrm{R} 3$ radicals and location of the unpaired bond electron within a radiation transformed alanine molecule. It had been discriminated that the prevailing free radicals $\mathrm{R} 1$ and $\mathrm{R} 2$ are structures with localisation of the unpaired electron at carbon atoms $\mathrm{C}(2)$ and $\mathrm{C}(1)$, respectively, within the molecule $\mathrm{CH}_{3} \mathrm{C}(2) \mathrm{H}\left(\mathrm{NH}_{2}\right) \mathrm{C}(1) \mathrm{OOH}$, while the third free stable radical R3 is a set of three conformations of radical species with the localization of the unpaired electron at either $\mathrm{N}$ or $\mathrm{O}$ or $\mathrm{C}(2)$ atoms within an alanine molecule. Formation of these three (R1-R3) stable radicals through evolution of radiation induced transforms of alanine had been modelled using the density functional theory (DFT) 
and rather well understood [10-13]. Nevertheless, the spectral compositions (X-and $\gamma$-rays, high energy electrons, neutrons, protons) and wide range of doses, when using different radiation sources, complicate the alanine based dosimetry. At the initial stages of development of the alanine based dosimetry, a considerable non-linearity of ESR responses of alanine sensors was found [3] in the range of large collected doses, while a phenomenological expression [3, ] for the alanine ESR signal vs dose dependence had been derived for electrons [3, $]$ ] and neutrons [ [ ] The alanine dosimeters, in addition to applications in medical diagnostics and therapy, are also promising in the monitoring of radiation doses during high energy physics experiments at accelerator [14, 15, nuclear reactor as well as nuclear waste storage environments. Therefore, the search for a generalized functional linkage between ESR signals and irradiation fluences/doses including various types of irradiations is important.

In this study, the ESR spectrometry of the stable free radicals in commercial alanine dosimeters, induced by penetrative $\mathrm{X}$ - and $\gamma$-rays as well as neutron and stopped proton irradiations covering the dose range from a few Gy to a few MGy, has been performed in order to create the generalized calibration function for the wide range dosimetry. The simulations based on the cumulative generation of ESR active stable radicals $\mathrm{R} 1, \mathrm{R} 2$ and R3 enabled us to derive the generalized calibration model ascribed to the irradiation fluence from $10^{10}$ to $2 \times 10^{16}$ particle $/ \mathrm{cm}^{2}$ normalized using a $1 \mathrm{MeV}$ neutron equivalent.

\section{Samples and measurement regimes}

In this work, commercial alanine tablet type dosimeters with $4.80 \pm 0.1 \mathrm{~mm}$ diameter and $3.00 \pm 0.3 \mathrm{~mm}$ height were investigated. The mass of these dosimeters was $66 \pm 0.5 \mathrm{mg}$ and the mass ratio of alanine to binder was $0.96 / 0.04$. This set of samples was irradiated by $\mathrm{X}$ rays in the dose range of 5-10 kGy using a $6 \mathrm{MeV}$ linear accelerator Varian Clinac 600 C/D. Several dosimeters were irradiated using $355 \mathrm{keV}$ energy $\gamma$-rays produced by a VariSource 200 instrument, in the range of 10, 20 and 100 Gy doses. A few alanine tablets of the same type were irradiated by spallator $23 \mathrm{MeV}$ neutrons at the Louvain-la-Neuve Cyclotron irradiation facilities, where the range of $2 \times 10^{13}$ and $2 \times 10^{14} \mathrm{~cm}^{-2}$ of fluences was covered. Additionally, a few alanine tablets were irradiated by $8 \mathrm{MeV}$ protons at the Helsinki University Accelerator Laboratory facilities by collecting fluences of $6 \times 10^{14}$ and $7 \times 10^{15} \mathrm{~cm}^{-2}$. Thereby, the performed irradiations cover a wide range of doses and types of radiations (60 and $6 \mathrm{MeV} \mathrm{X}$-ray, $355 \mathrm{keV} \gamma$-rays, $23 \mathrm{MeV}$ spallator neutrons, $8 \mathrm{MeV}$ protons). The additional two sets of alanine samples irradiated by $\mathrm{X}$-rays covering the dose ranges of $0.5-10.5$ Gy and 3 Gy - 1 MGy were included into ESR spectra measurements to make a reference function within the dose vs signal intensity dependence.

The ESR measurements have been performed by using a Bruker Elexsys E580 X-band spectrometer and a Bruker Alanine Dosimeter Reader operating in the $8-10 \mathrm{GHz}$ microwave frequency range. The Bruker intensity etalon sample has always been exploited in measurements using an Elexsys E580 spectrometer to account for the changes of spectrometer sensitivity drift. To control the position of the ESR tube within a resonator chamber, the position of an ESR tube has been precisely calibrated by using a teflon "finger" which fixed the same tube insertion depth. This teflon finger was taken out after the ESR tube with the sample was fixed within the resonator chamber. The resonance microwave frequency and relevant MW power (varied in the range of $0.2-2.4 \mathrm{~mW}$ ) is initially defined when the Elexsys E580 spectrometer was employed. There, several MW power levels have been tried to find the optimal MW power for the sample under investigation and to avoid signal distortions. Ranges of saturation of the ESR signal are determined by examination of the ESR signal changes dependent on the applied MW power. A set of calibrated dosimeter inserts was exploited in measurements using the Alanine Dosimeter Reader. These Reader inserts contain additional internal reference samples to control the relevant alanine ESR signal intensity range and to exclude possible variations of the measurement regime. The routine dosimetry measurements are based on peak-to-peak ESR signal intensity measurements [16]. Nevertheless, the peak-to-peak and double integral ESR spectrum analysis techniques [17] have been applied in the range of the largest doses to determine the relation between the ESR signal and the concentration of free radicals.

All the irradiations and measurements were carried out at room temperature.

\section{Results and discussion}

The typical changes of the recorded ESR spectra, attributed to the linear ESR response range and to that within the saturated branch of the ESR signal vs the fluence/dose characteristic, are illustrated in Fig. 1 for neutron (a) and $8 \mathrm{MeV}$ proton (b) irradiated alanine dosimeters.

These spectra, especially for neutron irradiated sensors, contain a structure inherent for high energy photon and electron irradiated alanine. These spectra, recorded in dosimeters irradiated with low and moderate fluences, can be well approximated by composing 

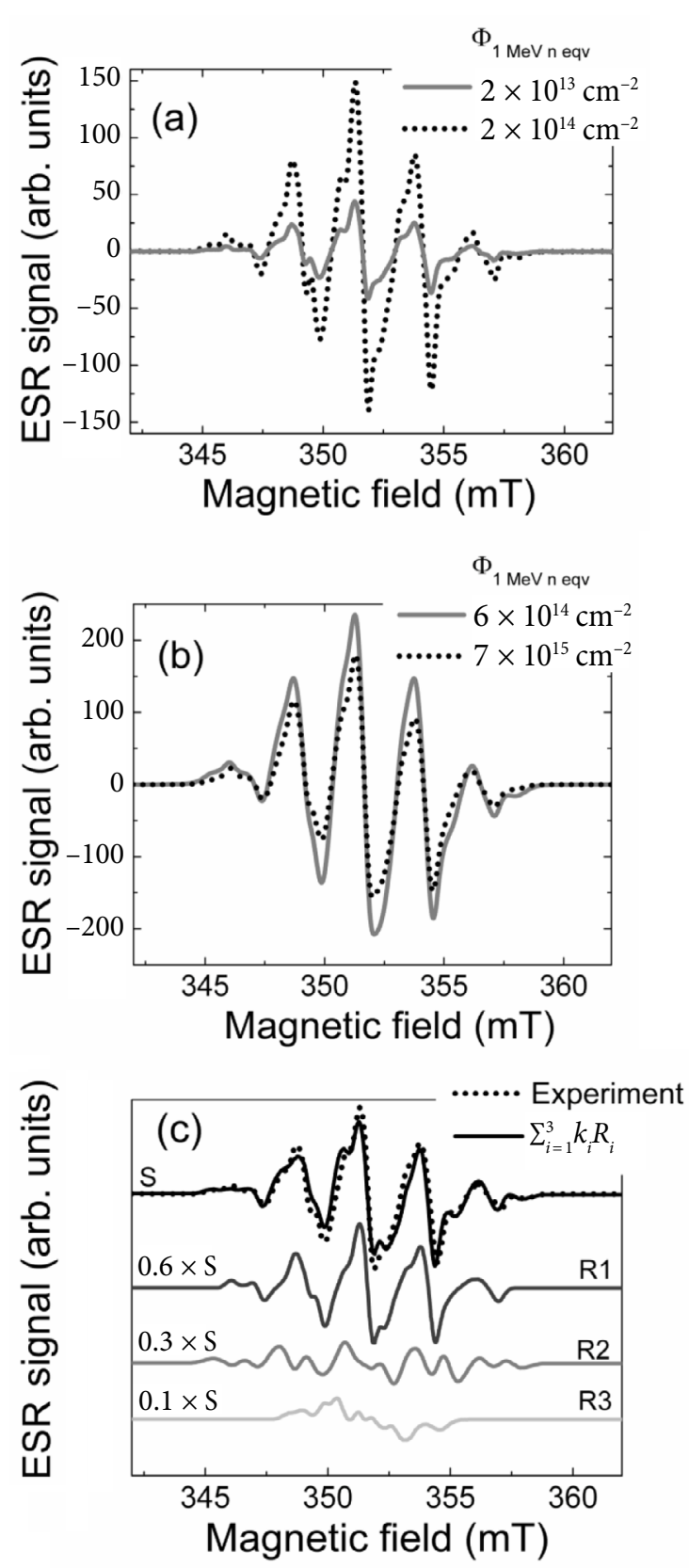

Fig. 1. ESR spectra recorded in the alanine dosimeters irradiated by $23 \mathrm{MeV}$ neutrons (a) and by $8 \mathrm{MeV}$ protons (b). Irradiation fluences, recalculated to the $1 \mathrm{MeV}$ neutron equivalent impacts, are denoted within the figure legends. (c) is the comparison of the simulated (solid line) and experimental (dot line) ESR spectra attributed to different radicals (R1, R2, R3 are solid grey lines) for alanine irradiated with X-rays at a dose of $50 \mathrm{kGy}$. Here, the spectra are arbitrarily shifted along an ordinate axis, to avoid overlap.

the constituents of the spectra ascribed to R1, R2 and R3 free radicals, with these simulated components taken from Ref. [6]. A spectral sum of the known radicals $\mathrm{R} 1, \mathrm{R} 2$ and $\mathrm{R} 3$ has been simulated by using the Spin Hamiltonian parameters taken from Ref. [6]. The same spectra changes were observed for X-ray irradiated samples. The comparison of simulated (solid line) and experimental (dot line) ESR spectra attributed to different radicals (R1, R2, R3 are solid grey lines) for alanine irradiated with X-rays at a dose of $50 \mathrm{kGy}$ is illustrated in Fig. 1(c). Simulations illustrated in Fig. 1.(c) were performed similarly to those taken from Ref. [6]. The ratio of peak amplitudes, assumed in Ref. [6] and ascribed to the radicals R1:R2:R3 $=0.6: 0.3: 0.1$, reproduces well the composite ESR spectrum. For the $8 \mathrm{MeV}$ proton irradiated sensors, the spectral peaks appear to be a little broadened, so these ESR resonances lose a tiny structure, resolvable for X-ray and neutron irradiated sensors.

To set a generalized ESR signal vs the fluence dependence, the values of $23 \mathrm{MeV}$ neutron fluence were recalculated assuming the radiation impacts equivalent to that of $1 \mathrm{MeV}$ neutrons and using the values of relative efficiencies reported in Ref. [15]. There, the $8 \mathrm{MeV}$ proton fluences were also recalculated to the $1 \mathrm{MeV}$ neutron equivalent impact. The $\mathrm{X}$ - and $\gamma$-ray fluences were evaluated using the calibrated dose values of the test dosimeters supplied to the Bruker Alanine Dosimeter Reader and assuming an average energy of photons characteristic of the X-ray tube spectrum, used for irradiations. The tablet sensor geometrical parameters were also exploited in the calculations of the cumulated X-and $\gamma$-ray fluence. The generalized over different types of irradiations characteristic of the ESR signal, recorded in the same alanine sensors, as a function of fluence is illustrated in Fig. 2. Additionally, the top scale denotes the values of irradiation doses.

The generalized distribution of the experimental ESR signals dependent on irradiation fluence appears as a rather contiguous spread of ESR signal values, irrespective of irradiation type in the range of fluences from $10^{10}$ to $10^{14}$ particle $/ \mathrm{cm}^{2}$. This collocation of ESR signal values exhibits a near-linear relation between the ESR response and fluence. However, the ESR signal dependence on the irradiation fluence starts to saturate when fluence values exceed that of $10^{14}$ particle $/ \mathrm{cm}^{2}$. Moreover, the values of the ESR signal for proton irradiated alanine have been obtained to be significantly less than those recorded in X-ray irradiated sensors for the range of saturated characteristic. The contiguous distribution of ESR signals dependent on irradiation fluence implies the possibility to model the generalized function which approximates the alanine dosimeter response irrespective of irradiation type.

Such a model has been created based on equal possibilities to form the free radicals of each type. However, it was assumed that radicals are stable and that a transformed alanine molecule cannot be further involved in the interaction with radiation. 


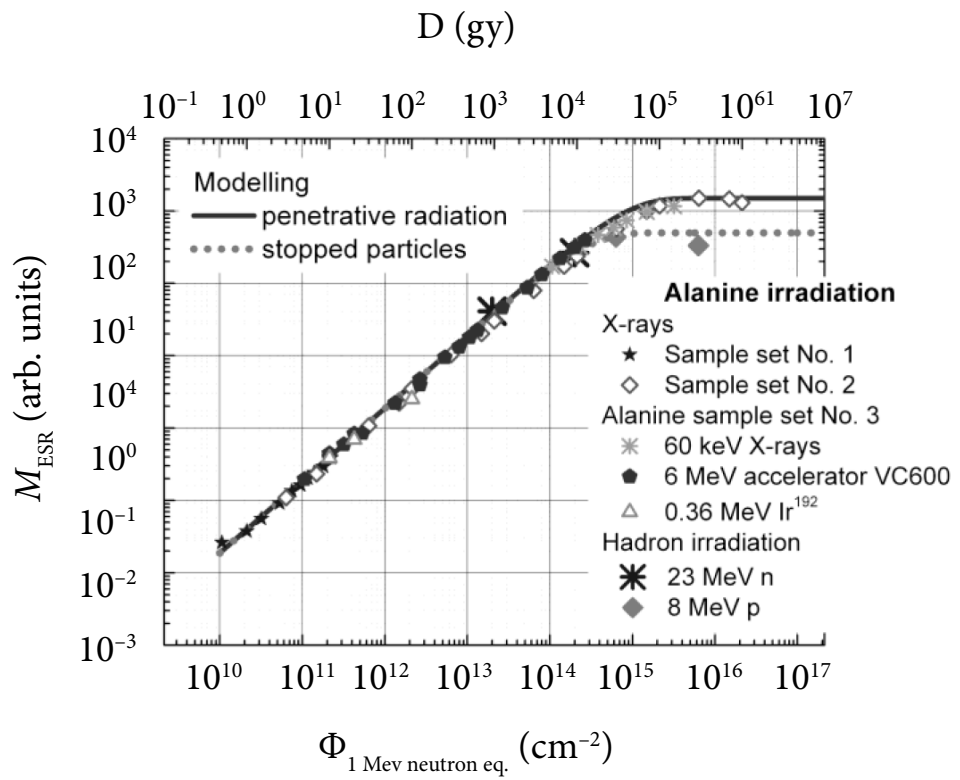

Fig. 2. The ESR central peak-to-peak signal recorded in the alanine dosimeters irradiated with different type particles (the respective irradiation type symbols are denoted in the legend) as a function of irradiation fluence. For hadron irradiations, the fluence values recalculated assuming the radiation impact equivalent to that of $1 \mathrm{MeV}$ neutrons were employed for this plot. Simulated ESR signal dependences as functions of fluence/dose for penetrative (solid curve) and stopped (dotted curve) radiation are also presented.
Then, the number $A$ of alanine molecules interacting with increasing irradiation fluence $\Phi$ should be reducing as

$$
A=A_{0} \exp (-K \Phi),
$$

where $A_{0}=m / \mu_{\text {alanine }}$ is the initial number of alanine molecules of the mass $\mu_{\text {alanine }}$ within the non-irradiated sensor of the mass $m$. The coefficient $K$ determines an effective cross-section for introduction of a free alanine radical ascribed to a single particle fluence impinging upon the dosimeter. This cross-section value is estimated by fitting of the experimental data using the simulation model. There the penetrative radiation is assumed relative to a thickness $d$ dosimeter. The interaction (between the impinging particle and alanine molecule) probability can be attributed to the relative absorption coefficient $\alpha_{\mathrm{at}} / \alpha_{\text {alanine }}$ (with the probability being proportional to this ratio) ascribed to an active atom $(\mathrm{C}, \mathrm{N}$ or $\mathrm{O})$ within an alanine molecule-free radical and normalized to the initial number of molecules $A_{0}$. The structure of each radical (R1-R3) and the number of atoms of different type $(\mathrm{C}, \mathrm{N}$ or $\mathrm{O})$ within the free radical is kept in mind when $\alpha_{\text {at }} / A_{0} \alpha_{\text {alanine }}$ is estimated. The relative values of $\alpha_{\mathrm{at}}$ ascribed to the processes of photo-ionisation and Compton scattering for $\mathrm{X}$-ray irradiated alanine sensors have been estimated using the data of measurements of the mass and linear attenuation taken from Refs. [18-20]. Also, it has been assumed that the radical $\mathrm{R}_{3}$ according to [6] is the composition of three conformations of radical species with the localization of the unpaired electron at different atoms. The backbone function for the generalized approximation model has been initially fitted to the Xray irradiated alanine sensors, as the largest quantity of samples in this study have been X-ray irradiated ones. The extracted number $M\left(\Phi_{\mathrm{T}}\right)$ of ESR active centres, related to the tested irradiation fluence $\Phi_{\mathrm{T}}$, can then be evaluated by the integration of the accumulated fluence as

$$
\begin{aligned}
& M\left(\Phi_{\mathrm{T}}\right)=\sum_{i=1}^{3} \frac{\alpha_{\mathrm{Ri}}}{A_{0} \alpha_{\text {alanine }}} S M_{\mathrm{S}} \int_{0}^{\Phi_{T}} A(\Phi) \mathrm{d} \Phi \\
& =\sum_{i=1}^{3} \frac{\alpha_{\mathrm{Ri}}}{A_{0} \alpha_{\text {alanine }}} A_{0} \frac{S M_{\mathrm{S}}}{K}\left(1-\mathrm{e}^{-K \Phi_{\mathrm{T}}}\right) .
\end{aligned}
$$

Here, $M_{\mathrm{S}}$ is the number of spins which determines the threshold sensitivity of ESR spectrometer, - in our case, it has been estimated to be $M_{\mathrm{S}} \cong 10^{10}$ for reliable detection of the $M\left(\Phi_{\mathrm{T}}\right)$ characteristic in the sensors of the area $S$.

The simulated generalized approximation function has been described by Eq. (2), which fitted satisfactorily the experimental data attributed to X-as well as $\gamma$-ray and neutron irradiated alanine dosimeters, and it is shown by a solid curve in Fig. 2. The fitting parameters of $K \cong 10^{-15} \mathrm{~cm}^{2}$ and $\Sigma_{i} \alpha_{\text {at, Ri }} / \alpha_{\text {alanine }} \cong 5 \times 10^{3}$ have been obtained. It can be deduced from Fig. 2 that the generalized function represented by Eq. (2) approximates well the alanine dosimeter response over a wide range of fluences (from $10^{10}$ to $2 \times 10^{16}$ parti$\mathrm{cle} / \mathrm{cm}^{2}$ ) of X-as well as $\gamma$-ray and neutron irradiated alanine material. These types of radiation are penetrative for the examined $3 \mathrm{~mm}$ thick alanine dosimeters. The discrepancy for the data obtained on $8 \mathrm{MeV}$ proton irradiated dosimeters can be explained by the projectile length of these protons being significantly shorter than the dosimeter thickness $d$. Really, the stopping range for $8 \mathrm{MeV}$ protons was simulated 
using the TRIM platform [21], and it was found (Fig. 3) to be $\sim d / 3$. This means that the parameter of the effective cross-section should be modified by the factor of about 3 , to recover the function for the penetrative irradiation. The modified generalized approximation function applicable to the case of stopped protons is shown in Fig. 2 by a dot curve. This curve again fits well the generalized ESR response, only with different (relative to a solid curve) saturation value. Thereby, a rather universal and simple generalized approximation model has been created to fit the alanine dosimeter response (at least those types of dosimeters exploited in our study) dependent on irradiation fluence. This model could be useful for prediction of irradiation source features (through the parameter of fluence) and of the effect of irradiation dose on organic tissues.

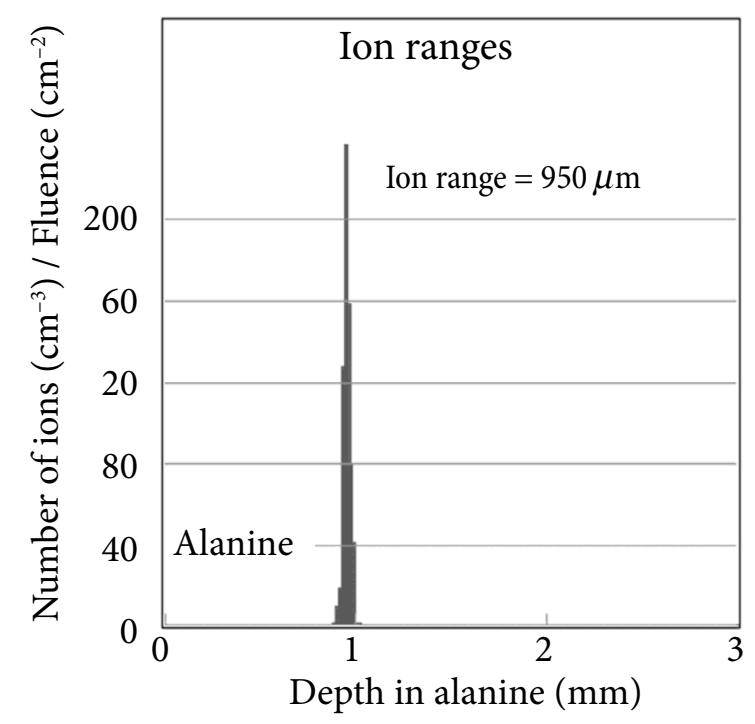

Fig. 3. Simulated projectile range for $8 \mathrm{MeV}$ protons into a $3 \mathrm{~mm}$ thick alanine sensor.

\section{Summary}

The ESR spectrometry of free radicals in alanine, induced by penetrative $\mathrm{X}$ - and $\gamma$-rays as well as neutron and stopped proton irradiations covering a dose range from a few Gy to a few MGy, has been performed. The simulations based on the cumulative generation of ESR active stable radicals R1, R2 and R3 enabled us to derive the generalized calibration model ascribed to the irradiation fluence from $10^{10}$ to $2 \times 10^{16}$ particle/ $\mathrm{cm}^{2}$ and normalized to a $1 \mathrm{MeV}$ neutron equivalent.

\section{Acknowledgements}

This study was partially supported by the Lithuanian Academy of Sciences Grant MA-CERN-rd39.

\section{References}

[1] W.L. McLaughlin, ESR dosimetry, Radiat. Prot. Dosim. 47(1/4), 255-262 (1993).

[2] Bruker (online), https://www.bruker.com/products $\mathrm{mr} / \mathrm{epr}$ /e-scan/alanine-dosimeter-reader/overview. html, accessed: 26/06/2015.

[3] J. Rotblat and J.A. Simmons, Dose-response relationship in the yield of radiation-induced free radicals in amino acids, Phys. Med. Biol. 7, 489-497 (1963).

[4] F. Callens, K. Van Laere, W. Mondelaers, P. Matthys, and E. Boesman, A study of the composite character of the ESR spectrum of alanine, Appl. Radiat. Isot. 47(11/12), 1241-1250 (1996).

[5] K.J. Olsen, J.W. Hansen, and M. Wille, Response of the alanine radiation dosemeter to high-energy photon and electron beams, Phys. Med. Biol. 35(1), 43-52 (1990).

[6] E. Malinen, M.Z. Heydari, E. Sagstuen, and E.O. Hole, Alanine radicals, Part 3: Properties of the components contributing to the EPR spectrum of X-irradiated alanine dosimeters, Radiat. Res. 159(1), 23-32 (2003).

[7] M.P.R. Waligorski, G. Danialy, K. S. Loh, and R. Katz, The response of the alanine detector after chargedparticle and neutron irradiations, Appl. Radiat. Isot. 40(10-12), 923-933 (1989).

[8] S. Kuroda and I. Miyagawa, ENDOR study of an irradiated crystal of L-alanine: environment of the stable $\mathrm{CH}_{3} \mathrm{CHCO}_{2}^{-}$radical, J. Chem. Phys. 76, 3933-3944 (1982).

[9] K. Matsuki and I. Miyagawa, ENDOR study of an irradiated crystal of L-alanine: structure and the environment of the unstable $\mathrm{CH}_{3} \mathrm{CHCO}_{2}^{-}$radical, J. Chem. Phys. 76, 3945-3952 (1982).

[10]E. Sagstuen, E.O. Hole, S.R. Haugedal, and W.H. Nelson, Alanine radicals: structure determination by EPR and ENDOR of single crystals X-irradiated at 295 K, J. Phys. Chem. A 101(50), 9763-9772 (1997).

[11] P. Lahorte, F. De Proft, G. Vanhaelewyn, B. Masshaele, P. Cauwels, F. Callens, P. Geerlings, and W. Mondelaers, Density functional calculations of hyperfine coupling constants in alanine-derived radicals, J. Phys. Chem. A 103(33), 6650-6657 (1999).

[12]T.L. Petrenko, Transformation and structure of cation radicals in L- $\alpha$-alanine, J. Phys. Chem. A 106(1), 149-156 (2002).

[13]E. Pauwels, H. De Cooman, M. Waroquier, E.O. Holec, and E. Sagstuenc, Solved? The reductive radiation chemistry of alanine, Phys. Chem. Chem. Phys. 16, 2475-2482 (2014).

[14]M. Fuerstner, I. Brunner, D. Forkel-Wirth, S. Mayer, H. Menzel, H. Vincke, and I. Floret, First calibration of alanine and radio-photo-luminescence dosemeters to a hadronic irradiation environment, 
in: IEEE Proccedings of 2005 Particle Accelerator Conference (Knoxville, USA, 2005) pp. 3097-3099.

[15]H.M. Gerstenberg, J.W. Hansen, J.J. Coyne, and J. Zoetelief, Calculations of the relative effectiveness of alanine for neutrons with energies up to $17.1 \mathrm{MeV}$, Radiat. Prot. Dosim. 31(1-4), 85-89 (1990).

[16] Practice for Use of Alanine-EPR Dosimetry System, ISO International Standard ISO/WD 15566.1 (1998).

[17] G.R. Eaton, S.S. Eaton, D.P. Barr, and R.T. Weber, Qantitative EPR (Springer-Verlag, Wien, 2010).

[18] P.P. Pawar and G.K. Bichile, Molar extinction coefficients of some amino acids, J. Chem. Pharm. Res. 3(5), 41-50 (2011).
[19] P.P. Pawar and G.K. Bichile, Measurement of mass and linear attenuation coefficients of gamma-rays of alanine for $0.662,1.170,1.280$ and $1.330 \mathrm{MeV}$ photons, J. Appl. Chem. 1(1), 53-58 (2012).

[20] S.M. Seltzer, Calculation of photon mass energytransfer and mass energy-absorption coefficients, Radiat. Res. 136(2), 147-170 (1993).

[21]J.F. Ziegler, J.P. Biersack, and M.D. Ziegler, The Stopping and Range of Ions in Matter (SRIM, Chester, 2008).

\title{
AUKŠTŲJŲ ENERGIJŲ SPINDULIUOTĖMIS APŠVITINTO ALANINO ESR SPEKTROSKOPIJA PLATAUS DIAPAZONO DOZIMETRIJAI
}

\author{
T. Čeponis ${ }^{\text {a }}$,E. Gaubas ${ }^{\text {a }}$, J. Venius ${ }^{\text {b }}$, A. Cicinas ${ }^{\text {b }}$, F. Callens ${ }^{c}$, J. Kusakovskij ${ }^{c}$, H. Vrielinck ${ }^{\text {c }}$, \\ K. Mizohata ${ }^{\mathrm{d}}$, J. Raisanen ${ }^{\mathrm{d}}$, P. Tikkanen ${ }^{\mathrm{d}}$, \\ ${ }^{a}$ Vilniaus universiteto Taikomujų mokslų institutas, Vilnius, Lietuva \\ ${ }^{\mathrm{b}}$ Nacionalinis véžio institutas, Vilnius, Lietuva \\ ${ }^{\mathrm{c}}$ Gento universitetas, Gentas, Belgija \\ ${ }^{\mathrm{d}}$ Helsinkio universitetas, Helsinkis, Suomija
}

\section{Santrauka}

Aukštujų energijų fizikos eksperimentinès įrangos ir dalelių greitintuvų aplinkos stebėsenai, branduolinių reaktorių aplinkos bei branduolinio kuro atlieku monitoringui, medicinineje diagnostikoje ir terapijoje labai svarbu registruoti jonizuojančiujų spinduliuočių sukauptą foninę dozę, siekiant užtikrinti toje aplinkoje veikiančios elektroninès įrangos funkcionalumą, numatyti jos degradacijos trukmę ir įvertinti personalo radiacinę saugą. Minètiems taikymams būtinas apšvitos dozès įvertinimas ir apšvitos dozès sąsajos su šaltinių spinduliuočių integriniu srautu - apšvitos ittèkiu, sukuriamu ivvairaus tipo spinduliuočių. Šiame darbe buvo ištirtos elektronų sukinių rezonansų (ESR) spektro smailių alanine amplitudès priklausomybès nuo apšvitos dozès (plačiame, 0,5 Gy - 1 MGy intervale) paveikus ịvairiomis spinduliuotemis (60 ir $6 \mathrm{MeV}$ Rentgeno, $355 \mathrm{keV}$ gama, $23 \mathrm{MeV}$ spalatoriaus neutronais, $8 \mathrm{MeV}$ protonais). Ši dozinè ESR signalų alanine priklausomybè buvo susieta su įtèkių skale, kalibruota $1 \mathrm{MeV}$ energijos neutronų ekvivalentinèms pažeidoms. Sukurti fenomenologiniai modeliai kalibracinių ịtèkių ir dozių sąsajos funkcijoms aproksimuoti. 